\title{
Flavour production in ewe's milk and ewe's milk yoghurt, by single strains and combinations of Streptococcus thermophilus and Lactobacillus delbrueckii subsp bulgaricus, isolated from traditional Greek yoghurt
}

\author{
AIK Georgala, E Tsakalidou, I Kandarakis, G Kalantzopoulos \\ Laboratory of Dairy Research, Agricultural University of Athens, \\ Votanikos, lera Odos 75, 11855 Athens, Greece
}

(Received 6 October 1994; accepted 15 March 1995)

\begin{abstract}
Summary - The flavour production in ewe's milk by 5 Streptococcus thermophilus and 4 Lactobacillus delbrueckii subsp bulgaricus strains as well as by their 20 combinations in ewe's milk yoghurt was studied. Samples for analysis were taken after $24 \mathrm{~h}$ and 5 days of storage at $4^{\circ} \mathrm{C}$. The flavour compounds (acetaldehyde, acetone, diacetyl and ethanol) were extracted by ether microsteam distillation and were identified and quantitatively estimated by gas chromatography. The concentrations of flavour compounds varied considerably among the single strains and their combinations. Acetaldehyde was recognized as the major flavour component, while acetone, diacetyl and ethanol were produced in lower concentrations. The Lb bulgaricus strain s produced, generally, higher concentrations of acetaldehyde than the Str thermophilus ones. In the $24 \mathrm{~h}$ as well as in the 5-days ewe's milk yoghurt, the combination ACA-DC 116/ACA-DC 232 was found to produce the highest acetaldehyde concentration $\left(13.14 \mathrm{mg} \mathrm{kg}^{-1}\right)$. Changes in the concentrations of flavour compounds were also observed between the $24 \mathrm{~h}$ and 5-days samples.
\end{abstract}

flavour / ewe's milk / yoghurt / Str thermophilus / Lb bulgaricus

Résumé - Production de composés d'arôme dans le lait de brebis et dans le yaourt au lait de brebis par des cultures pures ou mixtes de Streptococcus thermophilus et Lactobacillus delbrueckii subsp bulgaricus isolées de yaourt grec traditionnel. La production de composés d'arôme par 5 souches de Str thermophilus et 4 souches de Lb bulgaricus dans le lait de brebis ainsi que par 20 combinaisons de ces souches dans le yaourt au lait de brebis a été étudiée. Les échantillons ont été prélevés après $24 \mathrm{~h}$ et 5 jours de conservation à $4^{\circ} \mathrm{C}$. Les composés volatils (acétaldéhyde, acétone, diacétyle et éthanol) ont été identifiés par chromatographie en phase gazeuse, après extraction et distillation à l'éther éthylique. Les concentrations de composés identifiés variaient considérablement entre les souches pures et leurs combinaisons. L'acétaldéhyde était le composé majeur produit par les souches pures et les souches mixtes, l'acétone, le diacétyle et l'éthanol étant produits à de plus faibles concentrations. Il a également été observé que les souches de Lb bulgaricus produisaient, en général, de plus grandes concentrations d'acétaldéhyde que celles de Str thermophilus. Dans les yaourts, la combinaison ACA-DC 116/ACA-DC 232 produisait la plus grande quantité d'acétaldéhyde $\left(13,14 \mathrm{mg} \mathrm{kg}^{-1}\right)$. 
Des différences de concentrations en composés d'arôme étaient également observées entre les échantillons conservés à $4^{\circ} \mathrm{C} 24 \mathrm{~h}$ et 5 jours.

arôme / lait de brebis /yaourt /Str thermophilus / Lb bulgaricus

\section{INTRODUCTION}

One of the most interesting aspects of the growth of lactic acid bacteria in milk is the production of various metabolites during fermentation. It is well recognized that products other than lactic acid may be elaborated by lactic acid starter bacteria. Small amounts of formic acid, acetic acid, ethanol, acetone, carbon dioxide, acetoin, diacetyl and acetaldehyde have been reported as metabolic products. Carbonyl compounds have been the subject of intensive research in recent years, because of their possible role in flavour balance or in flavour defects in dairy products. The ability to produce flavour compounds is widespread among the lactic acid bacteria.

Keenan et al(1966), Bottazzi and Dellaglio (1967), Bottazzi and Vescovo (1969), and Bottazzi et al (1973) have shown that strains of Streptococcus thermophilus and Lactobacillus delbrueckii subsp bulgaricus produce different amounts of carbonyl compounds, in particular acetaldehyde, when grown in skimmed cow's milk. Substances that contribute to flavour are particularly significant in the preparation of natural yoghurt. Carbonyl compounds comprise the main aromatic substances in yoghurt. Acetaldehyde is the compound that contributes mostly to the typical flavour of yoghurt. Yoghurt flavour continuously changes during manufacture and storage. Flavour changes may vary depending on the cultures, mix formulation, incubation and storage conditions (Tamime and Deeth, 1980; Bottazzi, 1983; Tamime and Robinson, 1985).

Although the growth and the biochemical activity of lactic cultures in cow's milk have been well investigated, little information is available on this aspect concerning milk from other mammalian species, such as ewes and goats (Goerner et al, 1971; Abrahamsen et al, 1978; Rysstad and Abrahamsen, 1987; Abrahamsen and Rysstad, 1991). In the present study, the production of flavour compounds - acetaldehyde, acetone, diacetyl and ethanol - in ewe's milk, by single strains, as well as in ewe's milk yoghurt prepared by mixed cultures of Streptococcus thermophilus and Lactobacillus delbrueckii subsp bulgaricus, was studied.

\section{MATERIALS AND METHODS}

\section{Starter cultures}

Five Streptococcus thermophilus strains (Str thermophilus ACA-DC 111, 115, 116, CNRZ 404,1198 ), four Lactobacillus delbrueckii subsp bulgaricus strains ( $L b$ bulgaricus ACA-DC 231 , 232, CNRZ 398, 1159) and their 20 combinations were studied. All strains were isolated from traditional Greek yoghurt. The ACA-DC strains belong to the collection of the Laboratory of Dairy Research (Agricultural University of Athens, Greece), while the CNRZ strains to the INRA collection (Jouy-en-Josas, France). Strains were stored at $-30^{\circ} \mathrm{C}$ in sterile skimmed milk $10 \%$, containing $5 \%$ glycerol.

\section{Preparation of single strain samples}

Single strains were sub-cultured three times in skimmed milk, at $42^{\circ} \mathrm{C}$; then once in skimmed ewe's milk, previously heated at $100^{\circ} \mathrm{C}$ for 10 $\mathrm{min}$, until the $\mathrm{pH}$ reached 4.8 . Final growth was performed in fresh ewe's milk ( $2 \%$ inoculum); the milk previously tested for antibiotic residues and with a fat content standardized to $6.3 \%$, was heated at $95^{\circ} \mathrm{C}$ for $10 \mathrm{~min}$ and cooled to $45^{\circ} \mathrm{C}$ before inoculation. The inoculated milk was incubated at $42^{\circ} \mathrm{C}$ until the sample reached a $\mathrm{pH}$ of 4.6-4.7, at the end of incubation. The samples were then cooled, first at $30^{\circ} \mathrm{C}$ for $15 \mathrm{~min}$ and then at $20^{\circ} \mathrm{C}$ for $15 \mathrm{~min}$. Finally, samples were 
stored at $4^{\circ} \mathrm{C}$ and analysed after $24 \mathrm{~h}$ and 5 days of storage. Each experiment was duplicated.

\section{Preparation of ewe's milk yoghurt}

Single strains were sub-cultured three times in skimmed milk, at $42^{\circ} \mathrm{C}$; then once in skimmed ewe's milk, previously heated at $100^{\circ} \mathrm{C}$ for 10 min, until the $\mathrm{pH}$ reached 4.8 . Str thermophilus and $L b$ bulgaricus cultures were then mixed in a $1: 1$ ratio, and the mixed culture was used for inoculating fresh ewe's milk ( $2 \%$ inoculum). The milk previously tested for antibiotic residues and with a fat content standardized to $6.3 \%$, was heated at $95^{\circ} \mathrm{C}$ for $10 \mathrm{~min}$ and cooled to $45^{\circ} \mathrm{C}$ before inoculation. The inoculated milk was incubated in cups at $42^{\circ} \mathrm{C}$ up to $2.5-3.0 \mathrm{~h}$, until yoghurt reached $\mathrm{a} \mathrm{pH}$ of $4.6-4.7$ at the end of incubation. Cooling process was carried out in two stages; first at $30^{\circ} \mathrm{C}$ for $15 \mathrm{~min}$ and then at $20^{\circ} \mathrm{C}$ for $15 \mathrm{~min}$. Finally, yoghurt was stored at $4^{\circ} \mathrm{C}$ and analysed after $24 \mathrm{~h}$ and 5 days of storage. For the $24 \mathrm{~h}$ samples the $\mathrm{pH}$ ranged from 4.0 to 4.4 ; in the 5 -days samples from 4.0 to 4.2. Each experiment was duplicated.

\section{Extraction of volatile flavour compounds}

The ether extraction method described by Kang et al (1988) was used to extract flavour compounds. Sample $(30 \mathrm{~g})$ and distilled water $(30 \mathrm{~g})$ were mixed in the sample flask of the LickensNickerson micro-apparatus; diethyl ether $(3 \mathrm{ml})$ was placed in the solvent flask. The separation chamber was filled with $3 \mathrm{ml}$ of water and $3 \mathrm{ml}$ of diethyl ether, and the cold finger was connected to a cooling system $\left(-10^{\circ} \mathrm{C}\right)$. After boiling both flasks for $40 \mathrm{~min}$, distillation was stopped in the sample flask and continued for another $20 \mathrm{~min}$ in the solvent flask, to ensure complete extraction of the flavour compounds. The initial milk was also subjected to the same procedure. Each extraction was duplicated.

The extract obtained was analysed by gas chromatography (1 $\mu$ injection). Separation of volatiles was accomplished using a Hewlett Packard $5700 \mathrm{~A}$ gas chromatograph, equipped with a flame ionization detector (FID) and connected to a Variant 4270 Integator. Stainless steel packed columns $(2 \mathrm{~m} \times 3.18 \mathrm{~mm} \times 2 \mathrm{~mm}, 80-100$ mesh Hayesep Q) were used. The gas chromatographic conditions were as follows: injection temperature: $100^{\circ} \mathrm{C}$; initial temperature: $60^{\circ} \mathrm{C}$; final temperature: $200^{\circ} \mathrm{C}$; run time: $8 \mathrm{~min}$; temperature rate: $8^{\circ} \mathrm{C} / \mathrm{min}$; carrier gas $(\mathrm{He})$; flow rate: $30 \mathrm{ml} / \mathrm{min}$.

\section{Statistical analysis}

The results of the 9 single strains examined were statistically tested by analysis of variance using the statistical software package Statgraphics plus 5.2. The interpretation of the results obtained for the 20 combinations of strains was performed by cluster analysis, using the software package BMDP (Statistical Software, 1982).

\section{RESULTS AND DISCUSSION}

Flavour production by single strains of Str thermophilus and Lb bulgaricus

The production of flavour compounds by single strains of Str thermophilus after $24 \mathrm{~h}$ and 5 days of storage at $4^{\circ} \mathrm{C}$ is shown in table I. In the $24 \mathrm{~h}$ samples, the concentrations of acetaldehyde, acetone, diacetyl and ethanol varied from 1.00 to $2.52,0.19$ to $1.45,0.49$ to 0.71 and 0.07 to $0.35 \mathrm{mg} \mathrm{kg}^{-1}$, respectively. The highest concentrations of acetaldehyde, acetone and ethanol were produced by strain ACA-DC 111; strain CNRZ 404 produced the highest concentration of diacetyl. According to the analysis of variance by the method of the least significant difference (LSD method, significance level at $P<0.001$ ), there were statistically significant differences in the produced quantities of acetaldehyde and acetone among the 5 strains of Str thermophilus examined. However, this was shown not to be the case for diacetyl (strains ACADC 115, ACA-DC 111, ACA-DC 116) and for ethanol (strains CNRZ1198 and CNRZ 404).

After 5 days of storage the concentrations of flavour compounds varied from 1.30 to 1.67 (acetaldehyde), 0.34 to 1.07 (acetone), 0.50 to 1.12 (diacetyl) and 0.06 to $0.42 \mathrm{mg}$ $\mathrm{kg}^{-1}$ (ethanol). The highest concentrations of acetaldehyde and acetone were produced by strain ACA-DC 116. Strains CNRZ 404 
Table I. Flavour compounds $\left(\mathrm{mg} \mathrm{kg}^{-1}\right)$ produced in ewe's milk by Str thermophilus and $L b$ bulgaricus strains after $24 \mathrm{~h}$ and 5 days of storage of samples at $4^{\circ} \mathrm{C}$.

Composés d'arôme $\left(\mathrm{mg} \mathrm{kg}^{-1}\right)$ produits par les souches pures de Str thermophilus et Lb bulgaricus dans le lait de brebis après conservation à $4^{\circ} \mathrm{C}$ pendant $24 \mathrm{~h}$ et 5 jours.

\begin{tabular}{|c|c|c|c|c|c|c|c|c|c|c|c|c|}
\hline \multirow[t]{2}{*}{ Strain } & \multicolumn{3}{|c|}{ Acetaldehyde } & \multicolumn{3}{|c|}{ Acetone } & \multicolumn{3}{|c|}{ Diacetyl } & \multicolumn{3}{|c|}{ Ethanol } \\
\hline & $24 h$ & $5 d$ & $P^{a}$ & $24 h$ & $5 d$ & $P$ & $24 h$ & $5 d$ & $P$ & $24 h$ & $5 d$ & $P$ \\
\hline \multicolumn{13}{|c|}{ Str thermophilus } \\
\hline ACA-DC 111 & 2.52 & 1.38 & $\star \star \star \star ~$ & 1.45 & 0.47 & $* * *$ & 0.61 & 0.50 & * & 0.35 & 0.29 & ns \\
\hline ACA-DC 115 & 1.59 & 1.64 & ns & 0.34 & 0.34 & ns & 0.57 & 0.60 & ns & 0.07 & 0.06 & ns \\
\hline ACA-DC 116 & 1.51 & 1.67 & * & 0.54 & 1.07 & ** & 0.62 & 0.87 & ** & 0.15 & 0.19 & ns \\
\hline CNRZ 404 & 1.00 & 1.47 & ** & 0.67 & 0.92 & * & 0.71 & 1.12 & ** & 0.24 & 0.21 & ns \\
\hline CNRZ 1198 & 1.22 & 1.30 & ns & 0.19 & 0.54 & ** & 0.49 & 0.64 & $\star *$ & 0.21 & 0.42 & ** \\
\hline \multicolumn{13}{|l|}{ Lb bulgaricus } \\
\hline ACA-DC 231 & 3.14 & 1.96 & $* * \star$ & 0.63 & 0.73 & * & 0.00 & 0.00 & & 0.16 & 0.31 & ** \\
\hline ACA-DC 232 & 2.84 & 3.38 & ** & 0.56 & 0.62 & * & 0.00 & 0.00 & & 0.00 & 0.32 & ** \\
\hline CNRZ 398 & 4.53 & 5.58 & ** & 0.16 & 1.18 & $* * *$ & 0.00 & 0.00 & & 0.25 & 0.40 & ** \\
\hline CNRZ 1159 & 2.99 & 4.98 & $\star \star \star \star$ & 0.12 & 0.80 & $\star \star \star \star ~$ & 0.00 & 0.00 & & 0.23 & 0.20 & ns \\
\hline
\end{tabular}

a Statistically significant differences * for $P<0.05 ;{ }^{* \star}$ for $P<0.01$; ${ }^{* \star *}$ for $P<0.001$; ns: not significant; values are the mean of two experiments.

a Valeurs significatives pour ${ }^{*} \mathrm{P}<0,05$; ${ }^{* *} \mathrm{P}<0,01$; ${ }^{* * *} \mathrm{P}<0,001$; ns : non significatif ; les valeurs représentent la moyenne de deux analyses.

and CNRZ 1198 produced the highest concentrations of diacetyl and ethanol, respectively. In most cases there was a statistically significant difference among the strains examined (LSD method, significance level at $P<0.001)$. No statistically significant difference was observed for acetaldehyde (strains ACA-DC 116 and ACA-DC 115), acetone (strains ACA-DC 111 and CNRZ 1198) and ethanol (strains ACA-DC 116 and CNRZ 404). Generally, an increase in acetaldehyde, acetone and diacetyl concentrations was observed after 5 days of storage, except for strain ACA-DC 111 (decrease). These changes were statistically significant different (table I), except for strain ACA-DC 115. No statistically significant changes were observed in the case of ethanol (table I), except for strain CNRZ 1198.
Table I presents also the production of flavour compounds by single strains of $L b$ bulgaricus after $24 \mathrm{~h}$ and 5 days of storage at $4^{\circ} \mathrm{C}$. In the $24 \mathrm{~h}$ samples, the concentrations of acetaldehyde, acetone and ethanol varied from: 2.84 to $4.53,0.12$ to 0.63 and 0.00 to $0.25 \mathrm{mg} \mathrm{kg}-1$, respectively. $L b$ bulgaricus strains did not produce any diacetyl. The highest concentration of acetaldehyde was produced by strain CNRZ 398. Strain ACA-DC 231 produced the highest concentration of acetone. The highest quantity of ethanol was produced by strains CNRZ 398 and CNRZ 1159. In most cases there was a statistically significant difference among the examined strains (LSD method-significance level at $P<0.001$ ), except for ethanol (strains CNRZ 398 and CNRZ 1159). 
After 5 days of storage the concentrations of flavour compounds varied from: 1.96 to 5.58 (acetaldehyde), 0.62 to 11.8 (acetone) and 0.20 to $0.40 \mathrm{mg} \mathrm{kg}^{-1}$ (ethanol). As in the $24 \mathrm{~h}$ samples no diacetyl was produced after 5 days of storage. The highest concentrations of aroma compounds were produced by strain CNRZ 398. In most cases there was a statistically significant difference among the strains examined (LSD method, significance level at $P<0.001$ ), except for ethanol (strains ACA-DC 231 and ACA-DC 232). Generally, an increase in acetaldehyde, acetone and ethanol concentrations was observed for all $L b$ bulgaricus strains, except for strain ACA-DC 231 (decrease in acetaldehyde). These changes were statistically significant different (table I), except for ethanol in the case of strain CNRZ 1159.

According to the results obtained, the predominant aroma compound produced by the single strains was acetaldehyde. $L b$ bulgaricus strains, produced, generally, higher concentrations of acetaldehyde in comparison to Str thermophilus strains. Lb bulgaricus strains produced no diacetyl. On the other hand, $L b$ bulgaricus strains produced lower concentrations of acetone than the Str thermophilus strains, after $24 \mathrm{~h}$ of storage. Nevertheless, after 5 days of storage the acetone concentration in the case of $L b$ bulgaricus strains was higher than in the Str thermophilus ones. Ethanol was the aroma compound found in the lowest concentrations for both species. Almost no information is available concerning the production of flavour compounds by Str thermophilus and $L b$ bulgaricus single strains in ewe's milk. However, results presented in this study ranged generally at the same level as those reported for whole and/or skimmed cow's milk (Bottazzi and Dellaglio, 1967; Bottazzi and Vescovo, 1969; Hamdan et al, 1971; Dutta et al, 1973; Yu and Nakanishi, 1975; Bouillanne and Desmazeaud, 1980, 1981; Zourari, 1991); only Scolari (1987) reported for some strains considerably higher values.
The ratio between diacetyl and acetaldehyde after $24 \mathrm{~h}$ of storage at $4^{\circ} \mathrm{C}$ for the Str thermophilus strains tested ranged from 0.24 to 0.71: Therefore, according to Bottazzi (1975), who examined this ratio in cow's milk, none of the strains had an aroma described as an acetoin type. On the other hand, the $L b$ bulgaricus strains studied produced 2.84 $4.53 \mathrm{mg} \mathrm{kg}^{-1}(24 \mathrm{~h})$ and $1.96-5.58 \mathrm{mg} \mathrm{kg}^{-1}$ ( 5 days) acetaldehyde, and so characterised as having a good but not very full flavour, as determined by Bottazzi and Vescovo (1969) in skimmed cow's milk.

\section{Flavour production in ewe's milk yoghurt by combinations of Str thermophilus and Lb bulgaricus}

\section{Acetaldehyde}

As shown in table II, considerable differences in acetaldehyde production among the 20 combinations of strains were observed. The amount of acetaldehyde in the $24 \mathrm{~h}$ yoghurt varied from 2.54 (combination CNRZ 1198/ACA-DC 231) to $13.14 \mathrm{mg} \mathrm{kg}^{-1}$ (combination ACA-DC 116/ACA-DC 232). In the 5-days yoghurt the concentration varied from 1.65 (combination CNRZ 1198/ACA-DC 231) to $12.40 \mathrm{mg} \mathrm{kg}^{-1}$ (combination ACADC 116/ACA-DC 232). Two out of the 20 combinations presented an increase in acetaldehyde concentration after 5 days, in comparison to the $24 \mathrm{~h}$ yoghurt, while a decrease was determined in all the others. Combinations of $L b$ bulgaricus ACA-DC 232 with all Str thermophilus strains gave, generally, high amounts of acetaldehyde in the $24 \mathrm{~h}$ and 5-day yoghurt; the only exception was the combination CNRZ 1198/ACA-DC 232, which however showed a significant increase after 5 days of storage. The opposite occurred for the combinations of $L b$ bulgaricus ACA-DC 231 with all Str thermophilus strains. 
According to the results obtained in this study, acetaldehyde was found to be the main aroma component and its concentrations in the $24 \mathrm{~h}$ yoghurt (table II) were generally lower than those reported in the literature for cow's milk yoghurt; this was in agreement with the results presented by Goerner et al (1971). However, in some cases the amount of acetaldehyde produced (table II) was within the range reported by Veringa and Davelaar (1970), Vescovo (1970), and Hild (1979) for cow's milk yoghurt. Rasic and Kurmann (1978) reported that the content of acetaldehyde in cow's milk yoghurt should be in the range of $23-40 \mathrm{mg} \mathrm{kg}^{-1}$ in order to obtain a characteristic yoghurt flavour. Differences in the produced quantity of acetaldehyde in yoghurt can be attributed to the variations of streptococci and lactobacilli strains used, the type of milk, or the differences in the analytical methods employed to detect acetaldehyde. Tamime and Robinson (1985) claimed that one of the reasons for the observed changes in the behaviour of yoghurt starter cultures in the three different types of milk (cow's, goat's and ewe's) might be that both ewe's and goat's milk contain a substance which blocks the formation of a precursor required by the starter organism for the production of acetaldehyde.

According to the literature, yoghurt flavour is not fully formed at the end of incubation. During cooling and refrigeration changes in the concentration of flavour compounds may occur as a result of enzymatic reactions. No sufficient data for changes in acetaldehyde concentration in ewe's milk yoghurt during storage exist. However, there are many studies which report decrease or maintenance in the acetaldehyde concentration in cow's milk yoghurt during storage (Hamdan et al, 1971; Bills et al, 1972; Goerner et al, 1972; Vanderpoorten and Waes, 1972; Yu and Nakanishi, 1975; Kondratenko and Guiocheva, 1978; Abrahamsen and Rysstad, 1991). Only Kang et al (1988) observed an increase in the content of acetaldehyde after 10 days of storage of cow's milk yoghurt at $4^{\circ} \mathrm{C}$. In this meaning, the decrease in acetaldehyde concentration observed in the present study was in agreement with the data reported in literature for cow's milk yoghurt.

\section{Acetone}

From table III, it is evident that there were significant differences in the quantity of acetone produced by the different combinations of strains. In the $24 \mathrm{~h}$ yoghurt the produced quantities of acetone ranged from 0.23 (combination ACA-DC 1115/ACA-DC 232) to $3.26 \mathrm{mg} \mathrm{kg}^{-1}$ (combination ACA-DC 111/CNRZ 398). Lb bulgaricus CNRZ 398 combined with three Str thermophilus strains produced high amounts of acetone, compared with the other combinations.

The contrary occurred with the combinations of $L b$ bulgaricus CNRZ 1159 with most of the Str thermophilus strains. After 5 days of storage at $4^{\circ} \mathrm{C}$ the acetone concentration varied from 0.00 (combination CNRZ $1198 / A C A-D C 232$ ) to $1.39 \mathrm{mg} \mathrm{kg}^{-1}$ (combination CNRZ 404/CNRZ 398) (table III). In most of the combinations examined a decrease or maintenance of acetone amount was observed, with only a few exceptions. Combination CNRZ 404/CNRZ 398, with low acetone concentration after $24 \mathrm{~h}$, showed an important increase after 5 days of storage; this resulted in the highest acetone concentration determined in the 5-days yoghurt.

Only limited information is available concerning the acetone production in yoghurt and all data refer mainly to cow's milk yoghurt. Small quantities of acetone originate usually from milk, but certain quantities are produced by the yoghurt bacteria. Vescovo (1970) reported $4.00 \mathrm{mg} \mathrm{kg}^{-1}$ acetone in cow's milk yoghurt. Yu and Nakanishi (1975) detected $1.30 \mathrm{mg} \mathrm{kg}^{-1}$ acetone in cow's milk yoghurt, while according to Hild (1979) the acetone concentration in cows'milk yoghurt varied from 0.30 to $1.30 \mathrm{mg} \mathrm{kg}^{-1}$. Few re- 
Table II. Grouping, after statistical analysis, of the combinations of strains (yoghurt) according to the acetaldehyde $\left(\mathrm{mg} \mathrm{kg}^{-1}\right)$ produced in ewe's milk after $24 \mathrm{~h}$ and 5 days of storage at $4^{\circ} \mathrm{C}$.

Classement des combinaisons de souches en groupes d'après leur production d'acétaldéhyde $\left(\mathrm{mg} \mathrm{kg}{ }^{-1}\right)$ dans le yaourt de lait de brebis et après conservation à $4^{\circ} \mathrm{C}$ pendant $24 \mathrm{~h}$ et 5 jours.

\begin{tabular}{|c|c|c|c|c|c|}
\hline \multicolumn{3}{|c|}{$24 h$} & \multicolumn{3}{|c|}{5 days } \\
\hline Group & Combination & $m g k^{-1}$ & Group & Combination & $m g k^{-1}$ \\
\hline 1 & $116 / 232$ & 13.14 & 1 & $116 / 232$ & 12.40 \\
\hline \multirow[t]{4}{*}{2} & $404 / 232$ & 8.23 & 2 & $404 / 232$ & 6.36 \\
\hline & & & & $115 / 232$ & 5.40 \\
\hline & & & & $1198 / 232$ & 5.37 \\
\hline & & & & $111 / 232$ & 5.20 \\
\hline \multirow[t]{6}{*}{3} & $1198 / 398$ & 6.68 & 3 & $404 / 398$ & 4.82 \\
\hline & $116 / 1159$ & 6.44 & & $115 / 398$ & 4.57 \\
\hline & $116 / 398$ & 6.21 & & $111 / 398$ & 4.55 \\
\hline & $111 / 232$ & 6.20 & & $115 / 1159$ & 4.32 \\
\hline & $115 / 398$ & 6.07 & & $1198 / 398$ & 4.25 \\
\hline & $115 / 232$ & 5.93 & & & \\
\hline \multirow[t]{5}{*}{4} & $111 / 1159$ & 5.48 & 4 & $116 / 1159$ & 3.77 \\
\hline & $111 / 398$ & 5.14 & & $1198 / 1159$ & 3.72 \\
\hline & $116 / 231$ & 5.12 & & $111 / 1159$ & 3.61 \\
\hline & $115 / 1159$ & 4.73 & & $404 / 1159$ & 3.36 \\
\hline & $1198 / 1159$ & 4.41 & & $116 / 398$ & 2.97 \\
\hline \multirow[t]{7}{*}{5} & $404 / 1159$ & 4.14 & 5 & $116 / 231$ & 2.83 \\
\hline & $404 / 398$ & 4.10 & & $115 / 231$ & 2.72 \\
\hline & $404 / 231$ & 3.61 & & $111 / 231$ & 2.70 \\
\hline & $1198 / 232$ & 3.43 & & $404 / 231$ & 2.33 \\
\hline & $111 / 231$ & 3.36 & & $1198 / 231$ & 1.65 \\
\hline & $115 / 231$ & 3.23 & & & \\
\hline & $1198 / 231$ & 2.54 & & & \\
\hline
\end{tabular}

Str thermophilus: ACA-DC 111, 115, 116 and CNRZ 404, 1198. Lb bulgaricus: ACA-DC 231, 232 and CNRZ 398, 1159. Values are the mean of 2 experiments.

ports exist also on the effect of cooling and storage of yoghurt on acetone concentration. Kondratenko and Guiocheva (1978) observed a decrease in acetone concentration after 2 days of storage of cow's milk yoghurt. Kang et al (1988) reported decrease and/or maintenance of acetone in cow's milk yoghurt after 10 days of storage at $4^{\circ} \mathrm{C}$, depending on the determination method. Although the experimental data of the present work referred to ewe's milk yoghurt, it was evident that results obtained in the present study were in agreement with those reported for cow's milk yoghurt.

\section{Diacetyl}

As shown in table IV significant differences were observed in diacetyl production by the 20 combinations examined in the present study. The amount of diacetyl in the $24 \mathrm{~h}$ yoghurt varied from 0.00 ( 8 out of the 20 combi- 
nations) to $0.92 \mathrm{mg} \mathrm{kg}^{-1}$ (combination ACADC 115/CNRZ 398). After 5 days of storage of yoghurt at $4^{\circ} \mathrm{C}$, the amount of diacetyl varied from 0.00 ( 10 out of the 20 combinations) to $0.70 \mathrm{mg} \mathrm{kg}^{-1}$ (combination ACA-DC $116 / A C A-D C 232$ ). In most of the combinations a decrease or maintenance of diacetyl concentration was generally observed, with only a few exceptions (table IV). A considerable decrease of diacetyl quantity was observed in the case of combinations ACA-DC 116/CNRZ 398 and CNRZ 404/ACA-DC 231.
Concerning diacetyl production in ewe's milk yoghurt, there are not sufficient data. According to Rasic and Kurmann (1978) even small quantities of diacetyl, ranging from traces to $0.90 \mathrm{mg} \mathrm{kg}^{-1}$ or more contribute to the pleasant and delicate flavour and aroma of yoghurt. Groux (1973) claimed that its presence in yoghurt is important if the acetaldehyde content is low.

O'Leary and Woychik (1976) did not find any diacetyl in cow's milk yoghurt. According to Hild (1979), diacetyl content in cow's milk yoghurt varied from 1.0 to $8.5 \mathrm{mg} \mathrm{kg}^{-1}$. Marshall (1984)

Table III. Grouping, after statistical analysis, of the combinations of strains (yoghurt) according to the acetone $\left(\mathrm{mg} \mathrm{kg}^{-1}\right)$ produced in ewe's milk after $24 \mathrm{~h}$ and 5 days of storage at $4^{\circ} \mathrm{C}$.

Classement des combinaisons de souches en groupes d'après leur production d'acétone $\left(\mathrm{mg} \mathrm{kg}^{1}\right)$ dans le yaourt de lait de brebis et après conservation à $4^{\circ} \mathrm{C}$ pendant $24 \mathrm{~h}$ et 5 jours.

\begin{tabular}{|c|c|c|c|c|c|}
\hline \multicolumn{3}{|c|}{$24 h$} & \multicolumn{3}{|c|}{5 days } \\
\hline Group & Combination & $m g k^{-1}$ & Group & Combination & $m g k g^{-1}$ \\
\hline \multirow[t]{2}{*}{1} & $111 / 398$ & 3.26 & 1 & $404 / 398$ & 1.39 \\
\hline & & & & $116 / 398$ & 1.17 \\
\hline \multirow[t]{4}{*}{2} & $115 / 398$ & 1.03 & 2 & $116 / 232$ & 1.07 \\
\hline & $116 / 231$ & 1.02 & & $404 / 231$ & 1.04 \\
\hline & $404 / 1159$ & 0.98 & & $111 / 1159$ & 1.02 \\
\hline & $116 / 398$ & 0.90 & & $404 / 1159$ & 1.00 \\
\hline \multirow[t]{3}{*}{3} & $1198 / 232$ & 0.87 & 3 & $116 / 231$ & 0.76 \\
\hline & $116 / 232$ & 0.75 & & $404 / 232$ & 0.74 \\
\hline & & & & $115 / 231$ & 0.58 \\
\hline \multirow[t]{7}{*}{4} & $115 / 231$ & 0.56 & 4 & $1198 / 231$ & 0.45 \\
\hline & $111 / 231$ & 0.53 & & $115 / 398$ & 0.40 \\
\hline & $111 / 232$ & 0.51 & & $111 / 232$ & 0.39 \\
\hline & $1198 / 398$ & 0.51 & & $111 / 231$ & 0.35 \\
\hline & $404 / 398$ & 0.49 & & $111 / 398$ & 0.35 \\
\hline & $111 / 1159$ & 0.47 & & $1198 / 398$ & 0.32 \\
\hline & $404 / 231$ & 0.47 & & $115 / 1159$ & 0.31 \\
\hline \multirow[t]{6}{*}{5} & $404 / 232$ & 0.39 & 5 & $116 / 1159$ & 0.21 \\
\hline & $1198 / 231$ & 0.38 & & $115 / 232$ & 0.17 \\
\hline & $116 / 1159$ & 0.36 & & $1198 / 1159$ & 0.13 \\
\hline & $115 / 1159$ & 0.30 & & $1198 / 232$ & 0.00 \\
\hline & $1198 / 1159$ & 0.27 & & & \\
\hline & $115 / 232$ & 0.23 & & & \\
\hline
\end{tabular}

Str thermophilus: ACA-DC 111, 115, 116 and CNRZ 404, 1198. Lb bulgaricus: ACA-DC 231, 232 and CNRZ 398, 1159. Values are the mean of 2 experiments. 
claimed that the content of diacetyl in yoghurt rarely reaches $0.5 \mathrm{mg} \mathrm{kg}^{-1}$. Rysstad and $\mathrm{Ab}$ rahamsen (1987) found by gas chromatography $0.80 \mathrm{mg} \mathrm{kg}^{-1}$ diacetyl in cow's milk yoghurt and $0.85 \mathrm{mg} \mathrm{kg}^{-1}$ in goat's milk yoghurt, after $3 \mathrm{~h}$ of incubation. Only Brandao (1980) detected higher amounts of diacetyl (2-3 $\mathrm{mg} \mathrm{kg}^{-1}$ ) by gas chromatography, using the headspace technique. Regarding the effect of cooling and storage of yoghurt on diacetyl concentration, Kondratenko and Guiocheva (1978) have reported that diacetyl quantity increased until the formation of coagulum and decreased after the second day of storage of cow's milk yoghurt at $4^{\circ} \mathrm{C}$.

Kang et al (1988) compared an ether extraction method with a dynamic gas-purging headspace one for diacetyl determination in cow's milk yoghurt. According to the ether extraction method, diacetyl initially increased and then decreased during the storage of yoghurt for 10 days at $4^{\circ} \mathrm{C}$. On the contrary, when the headspace method was used, a continuous decrease of diacetyl quantity during storage was observed. Although the present work was performed on milk yoghurt, the results were in agreement with those reported for cow's milk yoghurt.

\section{Ethanol}

From table $\mathrm{V}$ it is obvious that after $24 \mathrm{~h}$ of storage the amount of ethanol varied from 0.00 (3 out of 20 combinations) to $0.59 \mathrm{mg} \mathrm{kg}^{-1}$ (combination CNRZ 1198/ACA-DC 232). Low amounts of ethanol 0.00 ( 3 out of 20 combinations) to $0.62 \mathrm{mg} \mathrm{kg}^{-1}$ (combination CNRZ 1198/ACA-DC 232) were also detected after 5 days of storage. The combination CNRZ $1198 / A C A-D C 232$ was the most active in both cases. After 5 days of storage in most of the combinations an increase or maintenance of the ethanol concentration was generally observed. A considerable increase was detected in the combination ACA-DC 111/CNRZ1159.
Ethanol in yoghurt is produced from acetaldehyde and its formation is ADH dependent. Small amounts of ethanol produced during lactic acid fermentation are of no practical importance in the flavour of yoghurt (Rasic and Kurmann, 1978). Rysstad and Abrahamsen (1987) determined by gas-chromatography $2.6 \mathrm{mg} \mathrm{kg}^{-1}$ ethanol in cows'milk yoghurt and $1.2-1.4 \mathrm{mg} \mathrm{kg}^{-1}$ in goat's milk yoghurt after a $3 \mathrm{~h}$ incubation. Hild (1979) reported that ethanol content in cow's milk yoghurt ranged from 1.4 to $4.1 \mathrm{mg} \mathrm{kg}^{-1}$. The quantities of ethanol determined in the present work (table V) for ewe's milk yoghurt were generally lower than those mentioned above. This might be due to absence and/or low ADH activity in the strains used, although this was not determined in the present study.

According to the results of the present work, in most of the combinations used for the preparation of ewe's milk yoghurt an increase or maintenance of ethanol quantity was observed after 5 days of storage of yoghurt at $4^{\circ} \mathrm{C}$. Only in 5 out of the 20 combinations a decrease of ethanol amount was observed after 5 of days storage. Almost no information is available concerning changes in ethanol concentration during storage. Kang et al (1988) compared an ether extraction method with a dynamic gas-purging headspace method for the determination of ethanol in cow's milk yoghurt. According to the ether extraction method ethanol increased slightly during storage of yoghurt at $4^{\circ} \mathrm{C}$, while no ethanol was detected by the headspace method. Although the present work was performed on ewe's milk yoghurt, the results were in agreement with those reported for cow's milk yoghurt.

\section{CONCLUSION}

From the above mentioned literature data, it is obvious that there is a discrepancy in the concentrations of flavour compounds determined. This is probably due to the different strains used, as well as to the type of milk and 
Table IV. Grouping, after statistical analysis, of the combinations of strains (yoghurt) according to the diacetyl $\left(\mathrm{mg} \mathrm{kg}^{-1}\right)$ produced in ewe's milk after $24 \mathrm{~h}$ and 5 days of storage at $4^{\circ} \mathrm{C}$.

Classement des combinaisons de souches en groupes d'après leur production diacétyle ( $\left.\mathrm{mg} \mathrm{kg}^{-1}\right)$ dans le yaourt de lait de brebis et après conservation à $4^{\circ} \mathrm{C}$ pendant $24 \mathrm{~h}$ et 5 jours.

\begin{tabular}{|c|c|c|c|c|c|}
\hline \multicolumn{3}{|c|}{$24 h$} & \multicolumn{3}{|c|}{5 days } \\
\hline Group & Combination & $m g k g^{-1}$ & Group & Combination & $m g k g^{-1}$ \\
\hline 1 & $115 / 398$ & 0.92 & 1 & $116 / 232$ & 0.70 \\
\hline \multirow[t]{7}{*}{ - } & $404 / 1159$ & 0.78 & & $404 / 1159$ & 0.63 \\
\hline & $116 / 231$ & 0.77 & & & \\
\hline & $116 / 232$ & 0.67 & 2 & $404 / 232$ & 0.54 \\
\hline & $116 / 398$ & 0.63 & & $116 / 231$ & 0.53 \\
\hline & $115 / 231$ & 0.63 & & $115 / 231$ & 0.50 \\
\hline & $404 / 232$ & 0.62 & & $115 / 398$ & 0.48 \\
\hline & $115 / 232$ & 0.56 & & & \\
\hline \multirow[t]{3}{*}{3} & $404 / 231$ & 0.47 & 3 & $404 / 398$ & 0.47 \\
\hline & $1198 / 232$ & 0.44 & & $1198 / 232$ & 0.41 \\
\hline & $1198 / 398$ & 0.38 & & $115 / 232$ & 0.41 \\
\hline 4 & $404 / 398$ & 0.21 & 4 & $1198 / 398$ & 0.23 \\
\hline \multirow[t]{10}{*}{5} & $111 / 231$ & 0.00 & 5 & $111 / 231$ & 0.00 \\
\hline & $111 / 232$ & 0.00 & & $111 / 232$ & 0.00 \\
\hline & $111 / 398$ & 0.00 & & $111 / 398$ & 0.00 \\
\hline & $111 / 1159$ & 0.00 & & $111 / 1159$ & 0.00 \\
\hline & $116 / 1159$ & 0.00 & & $116 / 1159$ & 0.00 \\
\hline & $115 / 1159$ & 0.00 & & $115 / 1159$ & 0.00 \\
\hline & $115 / 231$ & 0.00 & & $1198 / 231$ & 0.00 \\
\hline & $1198 / 1159$ & 0.00 & & $1198 / 1159$ & 0.00 \\
\hline & $1198 / 231$ & 0.00 & & $116 / 398$ & 0.00 \\
\hline & & & & $404 / 231$ & 0.00 \\
\hline
\end{tabular}

Str thermophilus: ACA-DC 111, 115, 116 and CNRZ 404, 1198. Lb bulgaricus: ACA-DC 231, 232 and CNRZ 398, 1159. Values are the mean of 2 experiments.

the methods used to determine these compounds. On the other hand, no data exist on the flavour development by Str thermophilus and $L b$ bulgaricus strains in ewe's milk. Therefore no reliable comparison can be performed to the results reported in literature for cow's milk. Finally, no data exist concerning the effect of refrigerated storage on the concentration of flavour compounds produced by single strains.
However, the results obtained in this study for ewe's milk fluctuated more or less with those reported in the literature for cow's milk. The concentrations of acetaldehyde, acetone, diacetyl and ethanol varied considerably among the single strains and their combinations. Acetaldehyde was recognized as the major flavour component, while acetone, diacetyl and ethanol were produced in lower concentrations. The $L b$ bulgaricus 
Table V. Grouping, after statistical analysis, of the combinations of strains (yoghurt) according to the ethanol $\left(\mathrm{mg} \mathrm{kg}^{-1}\right)$ produced in ewe's milk after $24 \mathrm{~h}$ and 5 days of storage at $4^{\circ} \mathrm{C}$.

Classement des combinaisons de souches en groupes d'après leur production d'éthanol ( $\left.\mathrm{mg} \mathrm{kg}^{-1}\right)$ dans le yaourt de lait de brebis et après conservation à $4^{\circ} \mathrm{C}$ pendant $24 \mathrm{~h}$ et 5 jours.

\begin{tabular}{|c|c|c|c|c|c|}
\hline \multicolumn{3}{|c|}{$24 h$} & \multicolumn{3}{|c|}{5 days } \\
\hline Group & Combination & $m g k g^{-1}$ & Group & Combination & $m g k^{-1}$ \\
\hline \multirow[t]{2}{*}{1} & $1198 / 232$ & 0.59 & 1 & $1198 / 232$ & 0.64 \\
\hline & & & & $111 / 1159$ & 0.55 \\
\hline \multirow[t]{3}{*}{2} & $404 / 1159$ & 0.35 & 2 & $116 / 398$ & 0.44 \\
\hline & $116 / 232$ & 0.32 & & $116 / 232$ & 0.39 \\
\hline & $116 / 231$ & 0.31 & & $404 / 231$ & 0.36 \\
\hline \multirow[t]{6}{*}{3} & $116 / 1159$ & 0.28 & 3 & $404 / 398$ & 0.29 \\
\hline & $1198 / 231$ & 0.26 & & $1198 / 231$ & 0.29 \\
\hline & $115 / 398$ & 0.25 & & $115 / 231$ & 0.27 \\
\hline & $115 / 1159$ & 0.24 & & $404 / 1159$ & 0.26 \\
\hline & $404 / 398$ & 0.21 & & & \\
\hline & $116 / 398$ & 0.21 & & & \\
\hline \multirow[t]{5}{*}{4} & $111 / 1159$ & 0.18 & 4 & $404 / 232$ & 0.18 \\
\hline & $115 / 231$ & 0.18 & & $115 / 232$ & 0.15 \\
\hline & $1198 / 398$ & 0.17 & & $115 / 398$ & 0.12 \\
\hline & $115 / 232$ & 0.14 & & & \\
\hline & $404 / 231$ & 0.12 & & & \\
\hline \multirow[t]{8}{*}{5} & $404 / 232$ & 0.07 & 5 & $116 / 1159$ & 0.09 \\
\hline & $1198 / 1159$ & 0.03 & & $115 / 1159$ & 0.08 \\
\hline & $111 / 398$ & 0.00 & & $116 / 231$ & 0.06 \\
\hline & $111 / 232$ & 0.00 & & $1198 / 1159$ & 0.03 \\
\hline & $111 / 231$ & 0.00 & & $1198 / 398$ & 0.01 \\
\hline & & & & $111 / 398$ & 0.00 \\
\hline & & & & $111 / 232$ & 0.00 \\
\hline & & & & $111 / 231$ & 0.00 \\
\hline
\end{tabular}

Str thermophilus: ACA-DC 111, 115, 116 and CNRZ 404, 1198. Lb bulgaricus: ACA-DC 231, 232 and CNRZ 398, 1159. Values are the mean of 2 experiments.

strains produced, generally, higher concentrations of acetaldehyde than the Str thermophilus ones. No diacetyl was determined for the Lb bulgaricus single strains, as well as for some of the combinations either after $24 \mathrm{~h}$ or 5 days of storage of samples at $4^{\circ} \mathrm{C}$. The combination ACA-DC 116/ACA-DC 232 was found to produce the highest acetaldehyde quantities, not only in the $24 \mathrm{~h}$ but also in the 5-day ewe's milk yoghurt. Changes in the concentrations of flavour compounds were also observed between the $24 \mathrm{~h}$ and the 5day samples. In general, in the case of single strains increase or maintenance was observed for all flavour compounds. On the other hand, in the case of the 20 combinations of strains decrease or maintenance was mostly observed for acetaldehyde, acetone and diacetyl while increase or maintenance was found for ethanol. 


\section{REFERENCES}

Abrahamsen RK, Rysstad G (1991) Fermentation of goat's milk with yoghurt starter bacteria: A review. Cult Dairy Prod J 26, 20-26

Abrahamsen RK, Svensen A, Tufto GN (1978) Some bacteriological and biochemical activities during the incubation of yoghurt from goat's and cow's milk. 20th Int Dairy Congr, Paris E 828-829

Bills DD, Yang CS, Morgan ME, Bodyfelt FW (1972) Effect of sucrose on the production of acetaldehyde and acids by yoghurt culture bacteria. J Dairy Sci 55, 1570-1573

BMDP Statistical Software (1982) University California Press, Los Angeles, CA

Bottazzi V (1975) Nouveaux aspects microbiologiques et technologiques dans la production du yoghurt. Sci Tec Latt-Casearia 26, 401-426

Bottazzi V (1983) Other fermented dairy products. In: Food and feed production with microorganisms (Reed G, ed) Verlag Chemie, Weinheim

Bottazzi V, Dellaglio F (1967) Acetaldehyde and diacetyl production by Streptococcus thermophilus and other lactic streptococci. J Dairy Res 34, 109-113

Bottazzi V, Vescovo M (1969) Carbonyl compounds produced by yoghurt bacteria. Neth Milk Dairy J 23, 71-78

Bottazzi V, Battistotti B, Montescani G (1973) Influence des souches seules et associées de $L$ bulgaricus et Str thermophilus ainsi que des traitements du lait sur la production d'aldéhyde acétique dans le yaourt. Lait 53, 295-308

Bouillanne C, Desmazeaud MJ (1980) Étude de quelques caractères de souches de Streptococcus thermophilus utilisées en fabrication de yoghourt et proposition d'une méthode de classement. Lait 60, 458-473

Bouillanne C, Desmazeaud MJ (1981) Classement de souches de Lactobacillus bulgaricus selon quelques caractères utilisés en fabrication du yoghourt. Association avec Streptococcus thermophilus. Sci Aliments 1, 7-17

Brandao SC (1980) Determination of volatile flavour constituents and residual carbohydrates during the fermentation of yoghurt. Michigan State University, $\mathrm{Ph} \mathrm{D}$ thesis (Dissertation Abstracts 41, 2541-B)
Dutta SM, Kuila RK, Ranganathan B (1973) Effect of different heat treatments of milk on acid and flavour production by five single strain cultures. Milchwissenschaft 28, 231-233

Goerner F, Palo V, Bertanova M (1971) Formation of volatiles substances in ewe's and goats' milk cultured with a yoghurt starter. Pol'nohospodarstvo 17, 378-383

Goerner F, Palo V, Seginova M (1972) Knof. novoj techn a technike vyr kyslom, vyr. a ost. mliec.spec., Vratna dol CSSR (24-26.10) p 60 Cit Rasic \& Kurman, Yoghurt

Groux M (1973) Étude des composants de la flaveur du yoghourt. Lait 53, 146-153

Hamdan IY, Kunsman Jr JE, Deane DD (1971) Acetaldehyde production by combined yoghurt cultures. J Dairy Sci 54, 1080-1082

Hild V (1979) Quantitative Bestimmung einiger wichtiger Aromakomponenten in Milcherzeugnissen mittles Head-Space-Technik. Milchwissenschaft $34,281-283$

Kang Y, Frank JF, Lillard DA (1988) Gas chromatographic detection of yoghurt flavour compounds and changes during refrigerated storage. Cult Dairy Prod J 23, (4) 6-9

Keenan TW, Lindsay RC, Morgan ME, Day EA (1966) Acetaldehyde production by singlestrain lactic streptococci. J Dairy Sci 49, 10-14

Kondratenko MS, Guiocheva BC (1978) Modifications des composants volatils du yoghourt bulgare. Lait 58, 390-396

Marshall VM (1984) Flavour development in fermented milks. In: Advances in the Microbiology and Biochemistry of Cheese and Fermented Milk (Davies FL, Law BA, eds) Elsevier Applied Science Publishers, London

O'Leary VS, Woychik JH (1976) A comparison of some chemical properties of yoghurts made from control and lactase treated milks. $J$ Food Sci $41,791-793$

Rasic JL, Kurmann JA (1978) Yoghurt: Scientific Grounds, Technology, Manufacture and Preparations. Volume 1. Technical Dairy Publishing House distributors, Copenhagen, Denmark

Rysstad G, Abrahamsen RK (1987) Formation of volatile aroma compounds and carbon dioxide in yoghurt starter grown in cow's and goats' milk. J Dainy Res 54, 257-266 
Scolari GL (1987) Aggiornamento di microbiologia dei batteri lattici. Centro Sperimentale del Latte, Milano

Tamime AY, Deeth HC (1980) Yoghurt: technology and biochemistry. J Food Prot 43, 939-977

Tamime AY, Robinson RK (1985) Yoghurt. Science and technology. Pergamon Press, Oxford

Vanderpoorten R, Waes G (1972) Study on the properties of some yoghurt cultures. Rev Agric Bruxelles 25, 101-114

Veringa HA, Davelaar S (1970) Enzymatic determination of acetadehyde in starter, yoghurt and butter. Neth Milk Dairy J 24, 34-44
Vescovo M (1970) Effect of milk composition and treatment on the formation of carbonyl compounds in yoghurt. Sci Tec Latt Casearia 21, 171-174

Zourari A (1991) Caractérisation de bactéries lactiques thermophiles isolées à partir des yaourts artisanaux grecs. Thèse de Doctorat, INA-PG Paris-Grignon, France

Yu JH, Nakanishi T (1975) Studies on production of flavour constituents by various lactic acid bacteria. II. Effect of milk fat on formation of volatile carbonyl compounds by various lactic acid bacteria. Jpn J Dairy Sci 24, A27-A31 